\title{
Evaluasi Alternatif Cross Drain di Ruas Jalan Nasional Selat Lampa - Teluk Depih - Simpang Sekunyam, Kepulauan Natuna
}

\author{
Evaluation of Cross Drain Alternatives on the Selat Lampa - Teluk \\ Depih - Simpang Sekunyam National Road, Natuna Islands
}

\author{
Farid Effendi $^{1, \text { a) }}$, Indrasurya Budisatria Mochtar $^{2, b)}$, Soendiarto $^{3, \mathrm{c})}$, \& Zulkarnain ${ }^{4, \mathrm{~d})}$ \\ ${ }^{1)}$ Karyasiswa Magister Super Spesialis Kerjasama PUPR, Departemen Teknik Sipil, Institut Teknologi \\ Sepuluh November, Surabaya. \\ ${ }^{2)}$ Departemen Teknik Sipil, Institut Teknologi Sepuluh Nopember (ITS), Surabaya. \\ ${ }^{3)}$ Direktorat Pembangunan Jalan, Direktorat Jenderal Bina Marga, Kementerian Pekerjaan Umum \\ dan Perumahan Rakyat, Jakarta. \\ ${ }^{4)}$ Balai Pelaksanaan Jalan Nasional Kepulauan Riau, Direktorat Jenderal Bina Marga, Kementerian \\ Pekerjaan Umum dan Perumahan Rakyat, Batam.
}

Koresponden : ${ }^{a)}$ farid.effendi@pu.go.id, ${ }^{b)}$ indramochtar.mochtar@gmail.com,

${ }^{c)}$ soendiarto1970@gmail.com \& ${ }^{d)}$ mekizulkarnain@gmail.com

\begin{abstract}
ABSTRAK
Pembangunan jalan baru Selat Lampa - Teluk Depih - Sp. Sekunyam pada tahun 2018 hingga 2022 dengan panjang 14,9 km merupakan pengalihan trase dari jalan eksisting yang memiliki grade lebih dari $16 \%$ dengan tikungan tajam sehingga hanya mampu dilalui oleh kendaraan dengan bobot kurang dari 5 ton. Pada sta 0+000 08+240 sudah selesai dibangun pada tahun 2019. Untuk Sta 08+240 - 14+890 sedang dalam pengerjaan melalui paket kontrak tahun jamak tahun 2020 -2022. Pada Sta $10+750$ dan 11+700, perlu dilakukan evaluasi terhadap dimensi dan alternatif cross drain yang sesuai. Karena di atas lereng lokasi tersebut terlihat adanya daerah tangkapan hujan yang cukup luas yang diperkirakan dapat menghasilkan aliran air sungai yang cukup besar menuju ke laut. Metode analisis yang diterapkan pada penulisan ini meliputi analisis hidrologi yang bertujuan menghitung debit rencana dengan menggunakan metode rasional dan analisa hidrolika untuk menghitung kapasitas debit cross drain. Kedua hasil ini disesuaikan dengan kondisi kontur eksisting yang curam untuk pemilihan alternatif cross drain yang sesuai. Evaluasi menunjukkan debit limpasan pada kala ulang 50 tahun adalah $15,10 \mathrm{~m}^{3} /$ detik pada sta $10+750$, dan 25,55 $\mathrm{m}^{3} /$ detik pada sta $11+700$, maka ukuran box culvert yang direkomendasikan pada sta $10+750$ adalah tipe double $4,0 \mathrm{~m} \times 3,0 \mathrm{~m}$, dan pada sta $11+700$ adalah tipe double $6,0 \mathrm{~m}$ x 3,0 m. Setelah dilakukan penyesuain dengan kondisi eksisting, maka pada sta $10+750$ lebih sesuai jika menggunakan jembatan busur, sedangkan pada sta $11+700$ tetap menggunakan box culvert dengan penyesuaian cutting jalan pendekat atau dengan timbunan yang diperkuat.
\end{abstract}

Kata Kunci : manajemen aset infrastruktur jalan, preservasi jalan, cross drain, natuna, box culvert, analisis hidrologi

\section{PENDAHULUAN}

Jalan merupakan salah satu jenis prasarana transportasi darat yang memegang peranan penting bagi pengembangan suatu daerah. Kondisi jalan yang baik akan memudahkan 
mobilitas penduduk dalam melakukan kegiatan ekonomi dan sosial sehari-hari. Dalam menjaga kondisi jalan tetap laik fungsi hingga masa layan rencana jalan tersebut, dibutuhkan kegiatan preservasi jalan. Pelaksanaan preservasi jalan merupakan bagian dari manajemen aset dalam hal ini aset yang berupa jalan. Prinsip dasar manajemen aset infrastruktur merupakan tugas, pengetahuan dan sains untuk mengelola infrastruktur selama umur siklus hidupnya agar infrastruktur dapat berfungsi secara efektif, efisien, dan berkelanjutan (Suprayitno \& Soemitro, 2018). Salah satu aspek dalam manajemen aset adalah aspek permintaan - penyediaan. Keberadaan suatu fasilitas mengikuti fenomena permintaanpenyediaan sehingga pembangunan suatu fasilitas jalan harus disesuaikan dengan kebutuhan yang ada.

Pada Kepulauan Natuna diperlukan pembangunan jalan Selat Lampa - Teluk Depih Sp. Sekunyam yang merupakan salah satu perwujudan pembangunan infrastruktur di kepulauan Natuna untuk memenuhi permintaan akan kebutuhan jalan yang bisa menguhubungkan . Jalan ini akan menghubungkan Kota Ranai yang merupakan kota terbesar di Natuna dan merupakan lokasi bandara dengan Pelabuhan Selat Lampa. Sebenarnya selama ini kota Ranai dan Pelabuhan Selat Lampa memang sudah dihubungkan dengan jalan, tetapi jalannya relatif sempit dan sangat berkelok - kelok dengan grade lebih dari $16 \%$, sehingga perlu dibangun jalan alternatif yang lebih lebar dan lebih mempersingkat waktutempuh antara ke dua lokasi tersebut. Total panjang pembangunan pada jalan Selat Lampa Teluk Depih - Simpang Sekunyam adalah 14,980 Km; sampai saat ini yang sudah selesai dikerjakan dari Sta 0+000 - Sta 8+225. Pada Sta 0+000 - Sta 8+225 sudah selesai dikerjakan pada tahun 2019. Untuk pekerjaan pada Sta $8+225$ - Sta 14+980, masuk paket pekerjaan MYC tahun 2020 - 2022. Dikerjakan selama 540 hari, dimulai dari 08 September 2020 hingga 01 Maret 2022.

Pada sta $8+225$ - 14+980, terdapat 22 cross drain. Desain semua cross drain menggunakan box culvert dengan ukuran bervariasi mulai dari 1 X 1 hingga 3 X 3, tetapi terdapat 2 titik dengan dimensi cross drain yang cukup besar, yaitu pada Sta 10+750 dan Sta 11+700. Memiliki kontur yang curam hingga kedalaman 16 meter. Pada awalnya hanya dianggap sebagai tipikal kontur daerah pegunungan, sehingga hanya dilakukan penanganan dengan timbunan saja. Ketika curah hujan tinggi terjadi aliran yang deras sehingga merusak timbunan yang ada. Jika dilihat lereng di atas lokasi tersebut terlihat adanya daerah tangkapan hujan yang cukup luas, yang diperkirakan dapat menghasilkan aliran air sungai yang cukup besar menuju ke laut. Oleh karena itu, perlu dilakukan evaluasi terhadap dimensi cross drain di 2 (dua) tempat tersebut, karena hingga saat ini belum pernah dilakukan evaluasi terhadap dimensi cross drain tersebut.

Dengan latar belakang permasalahan yang sudah diuraikan sebelumnya, pada pokoknya evaluasi yang perlu dilakukan pada studi ini adalah evaluasi pada rencana perlintasan dengan air (cross-drains) di Sta 10+750 dan 11+700 untuk menghindari adanya luapan air pada badan jalan ketika curah hujan tinggi. 

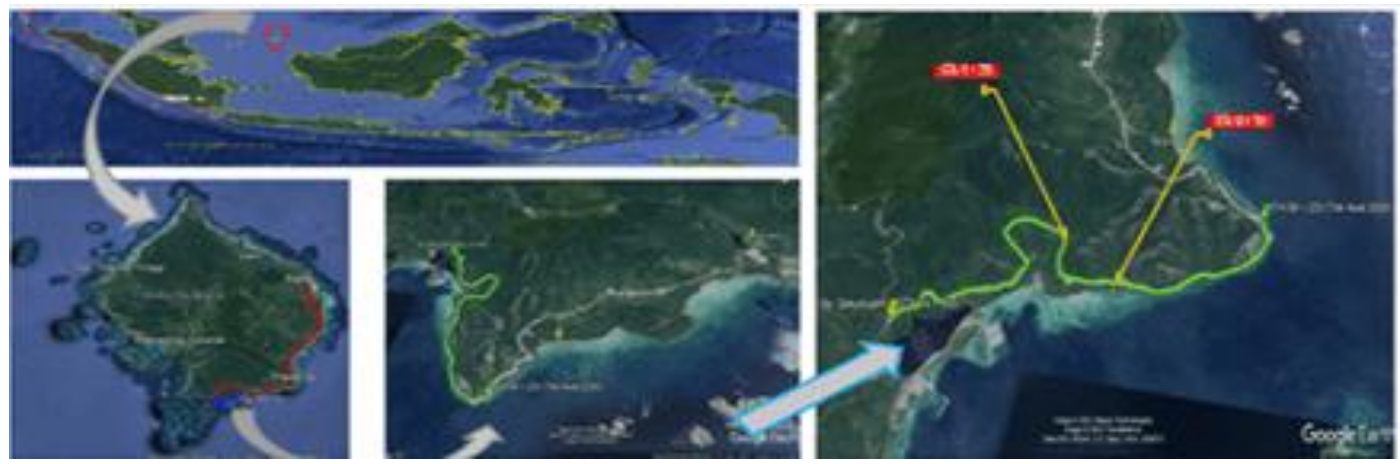

Gambar 1. Lokasi Sta 10+750 dan sta 11+700 pada Paket Pembangunan Jalan Selat Lampa - Teluk Depih -Sp. Sekunyam.

Sumber : Google Earth

\section{METODE PENELITIAN}

Penelitian ini akan dilakukan melalui beberapa jenis kegiatan yang saling terkait meliputi pengumpulan data, survei lapangan (ground check), identifikasi penggunaan lahan, perhitungan intensitas hujan, perhitungan koefesien limpasan rerata, perhitungan luas daerah tangkapan, perhitungan debit banjir beberapa kala ulang, evaluasi dimensi cross drain dan penyesuaian terhadap kondisi kontur eksisting. Metode yang digunakan dalam penelitian ini adalah Analisis hidrologi dan hidrolika untuk menentukan nilai debit rencana dan debit kapasitas.

\section{Pengumpulan Data}

Kondisi lapangan pada saat kunjungan dalam keadaan sudah tertimbun. Pada sta 10+750 kondisi timbunan masih tetap stabil belum ada tanda - tanda akan mengalami kerobohan karena terkena aliran air akibat hujan dari atas lereng. Sesuai kondisi di lapangan jarak antara badan jalan menuju tepi laut sepanjang 15 meter. Sesuai data shop drawing kedalamannya sebelum ditimbun mencapai 16 meter.

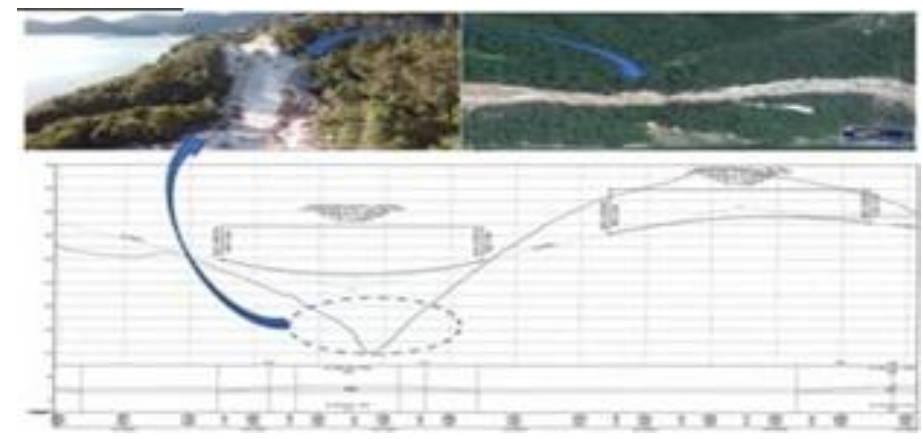

Gambar 2. Lokasi Sta $10+750$

Sumber : PPK 1.4 Provinsi Kepulauan Riau

Sedangkan pada sta 11+700 timbunan sudah mengalami kerusakan. Tampak gerusan akibat aliran air yang deras telah menghanyutkan sebagian timbunan. Sesuai gambar shop drawing kedalaman mencapai 8 meter. Jarak menuju lautan sejauh 200 meter 


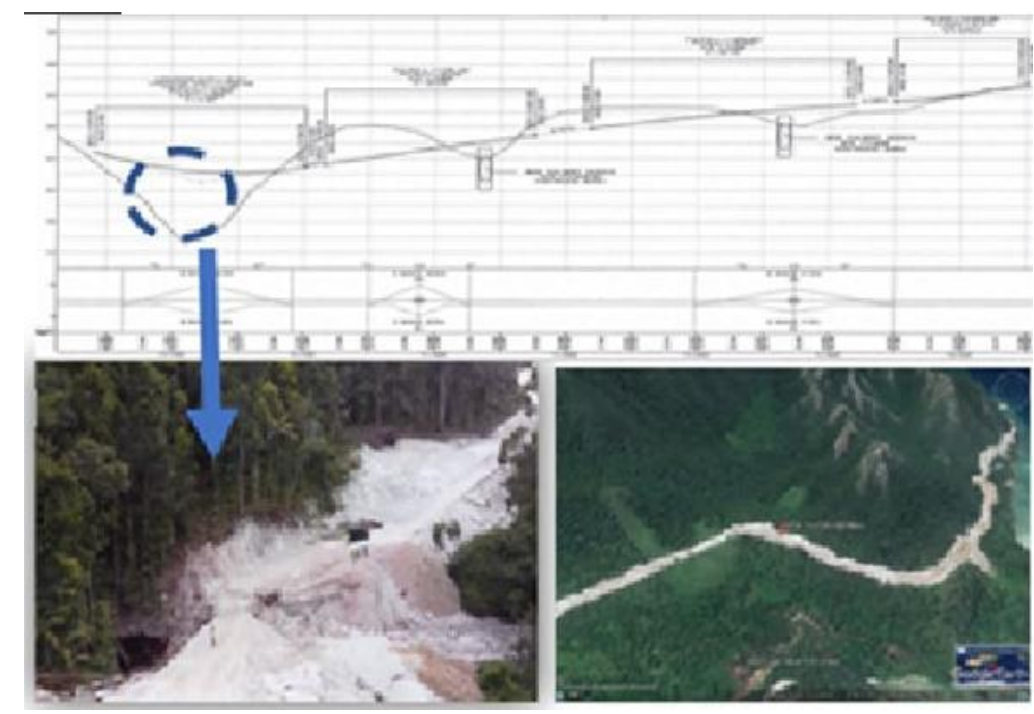

Gambar 3. Lokasi Sta 11+700

Sumber : PPK 1.4 Provinsi Kepulauan Riau

\section{Pengumpulan Data Sekunder}

1. Data Curah Hujan

Dalam analisis hidrologi data utama yang diperlukan adalah data curah hujan 10 tahun terakhir. Data ini didapat dari stasiun penakar hujan di Kota Ranai. Datanya adalah sebagai berikut :

Tabel 1. Data Curah Hujan Harian Maksimum

\begin{tabular}{crr}
\hline NO & Tahun & $\begin{array}{c}\text { Curah Hujan harian } \\
\text { Maksimum } \\
\text { (mm/hari) }\end{array}$ \\
\hline 1 & 2011 & 110 \\
2 & 2012 & 199 \\
3 & 2013 & 102,2 \\
4 & 2014 & 138 \\
5 & 2015 & 135 \\
6 & 2016 & 141,5 \\
7 & 2017 & 141,5 \\
8 & 2018 & 86,1 \\
9 & 2019 & 128,5 \\
10 & 2020 & 110 \\
\hline
\end{tabular}

Sumber : Badan Meteorologi Klimatologi dan Geofisika Stasiun Meteorologi Ranai - Natuna

2. Daerah tangkapan hujan

Daerah tangkapan hujan, daerah aliran sungai, suatu kawasan berupa cekungan yang dibatasi oleh pembatas topografi berupa igir yang di dalamnya terdapat jaringan sungai, dimana hujan yang jatuh kedalam kawasan ini dikeluarkan melalui satu keluaran (outlet) (Linsley et al,1975). Dalam penelitian ini data tersebut didapat dari perhitungan google earth. Pada sta 10+750 didapat daerah tangkapan hujan seluas 45 $\mathrm{km}^{2}$, dengan panjang aliran 1297 meter, kemiringan 20\% dan panjang limpasan mencapai 346 meter. 


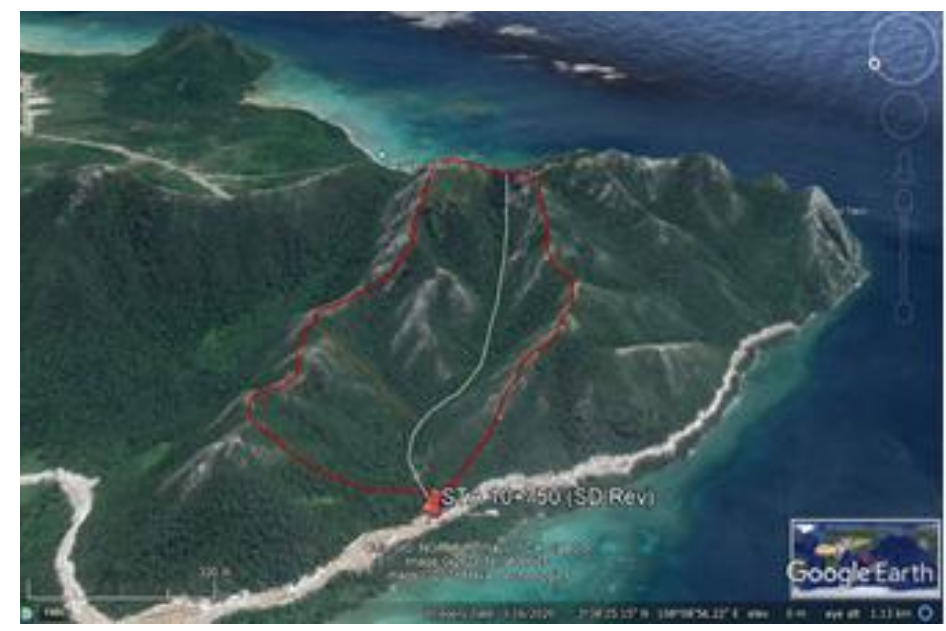

Gambar 4. Daerah tangkapan hujan pada sta 10+750

Sumber : Google earth

Sedangkan luasan daerah tangkapan hujan pada sta $11+700$ didapat $0,76 \mathrm{~km}^{2}$, dengan panjang aliran $1247 \mathrm{~m}$, kemiringan 18\%, dan panjang limpasan mencapai $697 \mathrm{~m}$. Untuk data titik koordinat lokasi kedua titik cross drain tersebut dari P2JN Provinsi Kepulauan Riau.

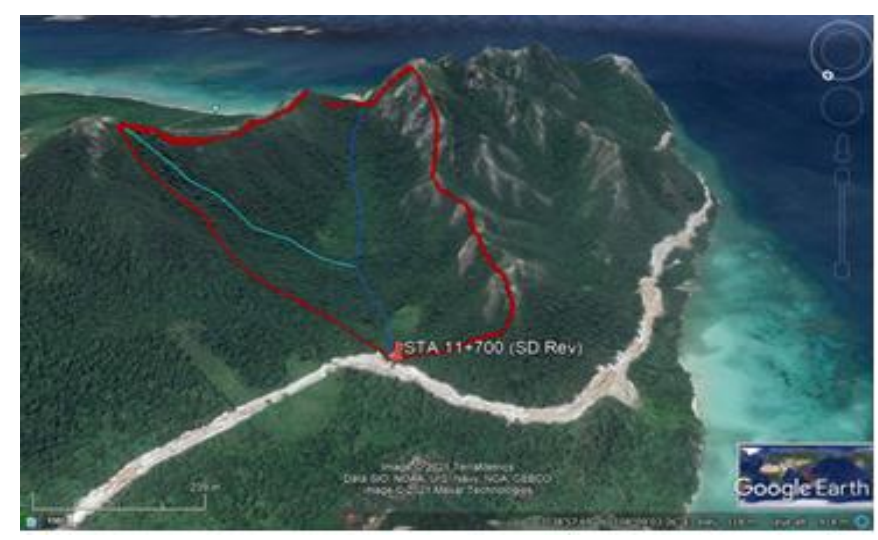

Gambar 4. Daerah tangkapan hujan pada sta $11+700$ Sumber : Google earth

\section{ANALISIS PENELITIAN}

\section{Analisis Hidrologi}

Analisis ini bertujuan menghitung curah hujan rencana pada Periode Ulang Hujan tertentu. Pada Tabel 1 menunjukkan nilai curah hujan hari maksimum selama 10 tahun terakhir (tahun 2010 hingga 2020) di stasiun penakar hujan yang ada di Kota Ranai. Data yang diambil adalah data curah hujan harian maksimum yang ada dalam satu tahun, agar evaluasi kapasitas cross drain berlaku saat hujan turun dalam curah yang maksimum.

Pemilihan fungsi distribusi yang digunakan dalam perhitungan analisis frekuensi didasarkan pada nilai parameter statistik dari data lapangan yang cocok atau mendekati fungsi distribusi yang berkaitan.

Dari nilai parameter statistik curah hujan wilayah di atas, didapat beberapa parameter statistik penting terdiri dari mean (rata-rata); standar deviasi (sd); koefisien variasi $(\mathrm{Cv})$; koefisien kemiringan; dan koefisien kurtosis (Ck). 
(e)ISSN 2615-1847 (p)ISSN 2615-1839

Jurnal Manajemen Aset Infrastruktur \& Fasilitas - Vol. 6, Edisi Khusus, Januari 2022

Tabel 3. Parameter statistik distribusi Normal dan Gumbel

\begin{tabular}{|c|c|c|c|c|c|c|c|c|}
\hline \multirow{2}{*}{ No } & \multirow{2}{*}{ Tahun } & $\mathrm{R}$ & $x_{i}$ & $x_{i}^{2}$ & $\left(X_{i}-X\right)$ & $\left(X_{i}-X\right)^{2}$ & $\left(X_{i}-X\right)^{3}$ & $\left(X_{i}-X\right)^{4}$ \\
\hline & & $(\mathrm{mm})$ & $(\mathrm{mm})$ & $(\mathrm{mm})^{2}$ & $(\mathrm{~mm})$ & $(\mathrm{mm})^{2}$ & $(\mathrm{~mm})^{3}$ & $(\mathrm{~mm})^{4}$ \\
\hline 1 & 2011 & 110 & 199 & $39.601,00$ & 69,78 & 4869,25 & 339776,15 & 23709579,98 \\
\hline 2 & 2012 & 199 & 141,5 & $20.022,25$ & 12,28 & 150,80 & 1851,80 & 22740,16 \\
\hline 3 & 2013 & 102,2 & 141,5 & $20.022,25$ & 12,28 & 150,80 & 1851,80 & 22740,16 \\
\hline 4 & 2014 & 138 & 138 & $19.044,00$ & 8,78 & 77,09 & 676,84 & 5942,62 \\
\hline 5 & 2015 & 135 & 135 & $18.225,00$ & 5,78 & 33,41 & 193,10 & 1116,12 \\
\hline 6 & 2016 & 141,5 & 128,5 & $16.512,25$ & $-0,72$ & 0,52 & $-0,37$ & 0,27 \\
\hline 7 & 2017 & 141,5 & 110 & $12.100,00$ & $-19,22$ & 369,41 & $-7100,03$ & 136462,57 \\
\hline 8 & 2018 & 86,1 & 110 & $12.100,00$ & $-19,22$ & 369,41 & $-7100,03$ & 136462,57 \\
\hline 9 & 2019 & 128,5 & 102,2 & $10.444,84$ & $-26,62$ & 708,62 & $-18863,58$ & 502148,54 \\
\hline 10 & 2020 & 110 & 86,1 & $7.413,21$ & $-43,12$ & 1859,33 & $-80174,50$ & 3457124,41 \\
\hline Jumlah & & & 1291,80 & $175.484,80$ & & 8588,64 & 231111,19 & 27994317,39 \\
\hline Rata rata & & & 129,18 & & & & & \\
\hline
\end{tabular}

$\bar{X}=\frac{1}{n} \sum_{i=1}^{n} X_{\mathrm{i}}=\frac{1}{10}(1291,8)=129,18$

$\mathrm{S}_{\mathrm{X}}=\sqrt{\frac{\frac{1}{n} \sum_{i=1}^{n}\left(X_{\mathrm{i}}-\bar{X}\right)^{2}}{n-1}}=\sqrt{\frac{8588,64}{10-1}}=30,89$

$\mathrm{C}_{\mathrm{v}}=\frac{\mathrm{Sx}}{\bar{X}}=\frac{129,18}{30,89}=0,24$

$\mathrm{C}_{\mathrm{s}}=\frac{n \times \sum_{i=1}^{n}(X i-\bar{X})^{3}}{(n-1)(n-2) s^{3}}=\frac{10 \times 231111,19}{(10-1)(10-2) 30,89^{3}}=1,089$

$\mathrm{C}_{\mathrm{k}}=\frac{n^{2} \times \sum_{i=1}^{n}(X i-\bar{X})^{4}}{(n-1)(n-2)(n-3) s^{4}}=\frac{10^{2} \times 27994317,39}{(10-1)(10-2)(n-3) 30,89^{4}}=6,09$

Tabel 4. Parameter statistik distribusi Log normal dan Log Pearson Type III

\begin{tabular}{cccccc}
\hline \multirow{2}{*}{ Tahun } & $\mathrm{Xi}$ & $\log \mathrm{Xi}$ & $\left(\log \mathrm{x}_{\mathrm{i}}-\log \bar{x}\right)^{2}$ & $(\log \mathrm{Xi}-\log \bar{x})^{3}$ & $(\log \mathrm{Xi}-\log \bar{x})^{4}$ \\
\cline { 2 - 6 } & $\mathrm{mm}$ & $\mathrm{mm}$ & $\mathrm{mm}^{2}$ & $\mathrm{~mm}^{3}$ & $\mathrm{~mm}^{4}$ \\
\hline 2011 & 110 & 2,041393 & 0,003514053 & $-0,000208311$ & $1,23486 \mathrm{E}-05$ \\
2012 & 199 & 2,298853 & 0,039275685 & 0,007783692 & 0,001542579 \\
2013 & 102,2 & 2,009451 & 0,008321315 & $-0,000759081$ & $6,92443 \mathrm{E}-05$ \\
2014 & 138 & 2,139879 & 0,001537185 & $6,02683 \mathrm{E}-05$ & $2,36294 \mathrm{E}-06$ \\
2015 & 135 & 2,130334 & 0,000879812 & $2,60967 \mathrm{E}-05$ & $7,7407 \mathrm{E}-07$ \\
2016 & 141,5 & 2,150756 & 0,002508438 & 0,000125633 & $6,29226 \mathrm{E}-06$ \\
2017 & 141,5 & 2,150756 & 0,002508438 & 0,000125633 & $6,29226 \mathrm{E}-06$ \\
2018 & 86,1 & 1,935003 & 0,027446212 & $-0,004546986$ & 0,000753295 \\
2019 & 128,5 & 2,108903 & $6,77492 \mathrm{E}-05$ & $5,57643 \mathrm{E}-07$ & $4,58996 \mathrm{E}-09$ \\
2020 & 110 & 2,041393 & 0,003514053 & $-0,000208311$ & $1,23486 \mathrm{E}-05$ \\
\hline \multicolumn{7}{c}{ Jumlah } & 21,00672 & 0,08957294 & 0,002399193 & 0,002405542 \\
\hline
\end{tabular}




$$
\begin{aligned}
& \bar{X}=\frac{1}{n} \sum_{i=1}^{n} X_{\mathrm{i}}=\frac{1}{10}(21,00672)=2,1 \\
& \mathrm{~S}_{\mathrm{x}}=\sqrt{\frac{\frac{1}{n} \sum_{i=1}^{n}\left(\log X_{\mathrm{i}}-\log \bar{X}\right)^{2}}{n-1}}=\sqrt{\frac{0,08957294}{10-1}}=0,0998 \\
& \mathrm{C}_{\mathrm{v}}=\frac{\mathrm{SX}}{\bar{X}}=\frac{0,0998}{2,1}=0,047 \\
& \mathrm{C}_{\mathrm{s}}=\frac{n \times \sum_{i=1}^{n}(\log X i-\log \bar{X})^{3}}{(n-1)(n-2) s^{3}}=\frac{10 \times 0,002399193}{(10-1)(10-2) 0,0998^{3}}=0,336 \\
& \mathrm{C}_{\mathrm{k}}=\frac{n^{2} \times \sum_{i=1}^{n}(\log X i-\log \bar{X})^{4}}{(n-1)(n-2)(n-3) s^{4}}=\frac{10^{2} \times 0,002405542}{(10-1)(10-2)(n-3) 0,0998^{4}}=4,818
\end{aligned}
$$

Dari serangkaian perhitungan yang telah dilakukan di atas maka dapat disimpulkan sebagai berikut :

Tabel 5. Hasil perhitungan parameter statistik

\begin{tabular}{cccc}
\hline No & Parameter & $\begin{array}{c}\text { Parameter } \\
\text { Statistik }\end{array}$ & $\begin{array}{c}\text { Parameter } \\
\text { Statistik } \\
\text { Logaritma }\end{array}$ \\
\hline 1 & Cv & 0,239 & 0,047 \\
2 & Cs & 1,089 & 0,336 \\
3 & Ck & 6,099 & 4,819 \\
\hline
\end{tabular}

Dari parameter diatas, dipilih jenis distribusi yang sesuai untuk digunakan dalam penelitian ini.

Tabel 6. Hasil perhitungan parameter statistik

\begin{tabular}{clrc}
\hline No Distribusi & Syarat & Hasil Hitungan & Keterangan \\
\hline 1 Normal & $\mathrm{Cs}=0$ & 1,089 & tidak \\
& $\mathrm{Ck}=3$ & 6,099 & diterima \\
\hline 2 Log Normal & $\mathrm{Cs}=\mathrm{Cv3}+3 \mathrm{Cv}=3$ & 0,336 & tidak \\
& $\mathrm{Ck}=5,383$ & 4,819 & diterima \\
\hline 3 Gumbel & $\mathrm{Cs}<1,14$ & 1,089 & tidak \\
& $\mathrm{Ck}<5,4$ & 6,099 & diterima \\
\hline 4 Log Pearson & $\mathrm{Cs} \neq 0$ & 0,336 & diterima \\
\hline
\end{tabular}

Dari tabel 6 didapat kesimpulan bahwa distribusi yang diterima ialah Log Pearson Tipe III. Selanjutnya dilakukan uji kecocokan. Uji kecocokan yang dilakukan ialah uji Chi Kuadrat dan Uji Smirnov-Kolmogorov. Berikut rekapitulasi dari uji tersebut.

Tabel 7. Hasil perhitungan parameter statistik

\begin{tabular}{lccc}
\hline \multicolumn{1}{c}{ Uji Kecocokan } & Syarat & Hasil & Keterangan \\
\hline Chi Square & 3,841 & 3,6 & Diterima \\
Smirnov-Kolmogorov & 0,41 & 0,2 & Diterima \\
\hline
\end{tabular}


Kesimpulan dari tabel diatas ialah dapat digunakannya metoda distribusi Log Perason Tipe III untuk menghitung hujan rencana. Berikut merupakan hasil perhitungan curah hujan rencana menggunakan Log Pearson Tipe III.

Tabel 8. Tinggi Curah Hujan Rencana pada PUH

\begin{tabular}{|c|c|c|c|c|}
\hline $\begin{array}{c}\text { PUH } \\
\text { (Tahun) }\end{array}$ & $\begin{array}{c}\text { Probability } \\
(\%)\end{array}$ & K & $\log X_{T}$ & $\begin{array}{c}\mathrm{R}_{\mathrm{T}} \mathrm{HHM} \\
(\mathrm{mm})\end{array}$ \\
\hline a & $b$ & C & $d=\log X_{i}+\left(K \times S_{x}\right)$ & $e=\operatorname{antilog}(d)$ \\
\hline 2 & 50 & $-0,066$ & 2,101659784 & 126,3746 \\
\hline 5 & 20 & 0,816 & 2,186168566 & 153,52127 \\
\hline 10 & 10 & 1,317 & 2,220387091 & 166,10668 \\
\hline 25 & 4 & 1,880 & 2,253109178 & 179,10561 \\
\hline 50 & 2 & 2,261 & 2,272263571 & 187,18178 \\
\hline
\end{tabular}

\section{Analisis Intensitas Hujan}

Perhitungan curah hujan rencana yang dipilih sebelumnya adalah perhitungan dengan metoda Log Pearson type III. Selanjutnya, perhitungan analisis intensitas hujan dilakukan dengan 3 metoda, yaitu Metoda Van Breen, Bell dan Hasper Weduwen. Berikut hasil perhitungan masing-masing metoda.

Tabel 9. Hasil Perhitungan Distribusi Intensitas Hujan PUH 50 Tahun dengan Ketiga Metoda

\begin{tabular}{rrrr}
\hline Durasi & \multicolumn{3}{c}{$\begin{array}{c}\text { Intensitas Hujan } \\
\text { (mm/jam) }\end{array}$} \\
\cline { 2 - 4 } (menit & \multicolumn{4}{c}{ Bell } & Van Breen & Hasper Weduwen \\
\hline 5 & 313,39 & 201,10 & 215,74 \\
10 & 234,56 & 176,89 & 150,60 \\
20 & 163,57 & 151,62 & 103,89 \\
40 & 109,31 & 120,03 & 70,15 \\
60 & 85,18 & 105,29 & 54,92 \\
80 & 71,02 & 91,60 & 45,74 \\
120 & 54,67 & 66,33 & 34,83 \\
240 & 34,51 & 42,12 & 20,89 \\
\hline
\end{tabular}

Perbandingan hasil perhitungan intensitas hujan dari ketiga metoda yang digunakan disajikan dengan grafik lengkung intensitas hujan. Metoda yang akan dipilih adalah metoda yang memiliki hasil perhitungan intensitas hujan mayoritas paling besar. Pemilihan nilai intensitas hujan paling besar karena untuk meningkatkan tingkat keamanan dalam mendesain cross drain. 


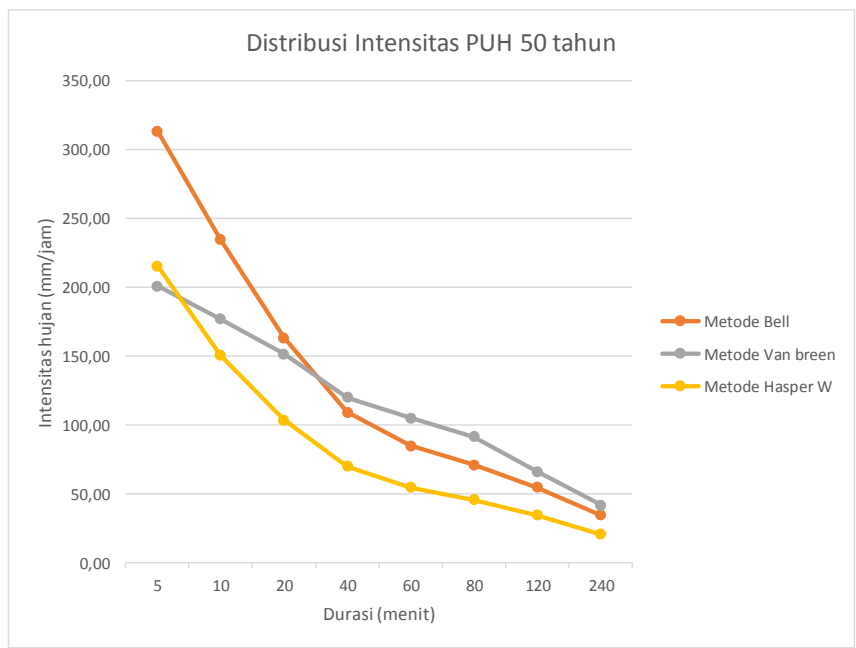

Gambar 5. Distribusi Intensitas Hujan PUH 50 Tahun

Berdasarkan Tabel 9dan Gambar 5 secara umum nilai intensitas hujan yang dihitung dengan metoda Van Breen lebih besar dari intensitas hujan yang dihitung dengan dua metoda lainnya, metoda Van Breen yang dipilih dan nilai intensitas ini akan digunakan untuk perhitungan selanjutnya.

\section{Perhitungan Intensitas Hujan Rencana}

Perhitungan intensitas hujan rencana menggunakan Metoda Talbot, Sherman dan Ishiguro. Dari hasil perhitungan ketiga metoda tersebut dipilih satu metoda yang mempunyai lengkung intensitas hujan terkecil. Perhitungan distribusi intensitas hujan yang terpilih sebelumnya adalah pehitungan dengan Metoda Van Breen dengan PUH 50 tahun untuk cross drain. Sehingga untuk analisis selanjutnya menggunakan intensitas hujan PUH 50 tahun untuk menghitung nilai-nilai variabel sebagai data masukan dalam rumus lengkung intensitas hujan. Perhitungan nilai variabel untuk ketiga metoda dapat dilihat pada Tabel 10 hingga Tabel 12.

Tabel 10. Nilai Variabel untuk Perhitungan Intensitas Hujan PUH 50 Tahun Metoda Talbot

\begin{tabular}{rrcccccc}
\hline $\mathrm{t}$ & $\mathrm{I}$ & $\mathrm{I} . \mathrm{t}$ & \multicolumn{1}{c}{$\mathrm{I}^{2}$} & $\mathrm{I}^{2} . \mathrm{t}$ & $\mathrm{a}$ & $\mathrm{b}$ & $\mathrm{I}$ \\
\hline $\mathrm{a}$ & $\mathrm{b}$ & $\mathrm{c}=\mathrm{a} \times \mathrm{b}$ & $\mathrm{d}=\mathrm{b}^{2}$ & $\mathrm{e}=\mathrm{b}^{2} \times \mathrm{a}$ & $\mathrm{f}$ & $\mathrm{g}$ & $\mathrm{h}=\mathrm{f} /(\mathrm{a}+\mathrm{g})$ \\
\hline 5 & 201,10 & 1005,517 & 40442,59 & 202212,936 & 12245,32062 & 58,26453308 & 193,5574 \\
10 & 176,89 & 1768,868 & 31288,93 & 312889,334 & 12245,32062 & 58,26453308 & 179,3804 \\
20 & 151,62 & 3032,345 & 22987,79 & 459755,757 & 12245,32062 & 58,26453308 & 156,4607 \\
40 & 120,03 & 4801,213 & 14407,28 & 576291,07 & 12245,32062 & 58,26453308 & 124,6159 \\
60 & 105,29 & 6317,385 & 11085,93 & 665155,898 & 12245,32062 & 58,26453308 & 103,5418 \\
80 & 91,60 & 7328,167 & 8390,94 & 671275,332 & 12245,32062 & 58,26453308 & 88,56444 \\
120 & 66,33 & 7959,905 & 4400,01 & 528000,752 & 12245,32062 & 58,26453308 & 68,69185 \\
240 & 42,12 & 10107,82 & 1773,75 & 425699,775 & 12245,32062 & 58,26453308 & 41,05524 \\
\hline Jumlah & 954,98 & 42321,22 & 134777,21 & 3841280,85 & & & \\
\hline
\end{tabular}


Tabel 11. Nilai Variabel untuk Perhitungan Intensitas Hujan PUH 50 Tahun Metoda Sherman

\begin{tabular}{|c|c|c|c|c|c|c|c|c|c|}
\hline $\mathrm{t}$ & I & $\log I$ & $\log t$ & $\log ^{2} \mathrm{I}$ & $\log 2 t$ & Logt.LogI & $\mathrm{a}$ & $\mathrm{k}$ & 1 \\
\hline a & $b$ & $c=\log b$ & $d=\log a$ & $e=c 2$ & $f=d 2$ & $g=c x d$ & $\mathrm{~h}$ & i & $\mathrm{l}=\mathrm{h} / \mathrm{a}^{\mathrm{i}}$ \\
\hline 5 & 201,10 & 2,30342 & 0,69897 & 5,3057412 & 0,48855907 & 1,610021114 & 347,836 & 0,386969084 & 186,593 \\
\hline 10 & 176,89 & 2,2477 & 1 & 5,0521345 & 1 & 2,24769538 & 347,836 & 0,386969084 & 142,694 \\
\hline 20 & 151,62 & 2,18075 & 1,30103 & 4,7556644 & 1,69267905 & 2,837219329 & 347,836 & 0,386969084 & 109,123 \\
\hline 40 & 120,03 & 2,07929 & 1,60206 & 4,3234509 & 2,56659622 & 3,33114884 & 347,836 & 0,386969084 & 83,4501 \\
\hline 60 & 105,29 & 2,02239 & 1,778151 & 4,0900455 & 3,16182187 & 3,596108369 & 347,836 & 0,386969084 & 71,3321 \\
\hline 80 & 91,60 & 1,96191 & 1,90309 & 3,8490726 & 3,6217515 & 3,733682428 & 347,836 & 0,386969084 & 63,8172 \\
\hline 120 & 66,33 & 1,82173 & 2,079181 & 3,318688 & 4,32299465 & 3,787699881 & 347,836 & 0,386969084 & 54,5501 \\
\hline 240 & 42,12 & 1,62445 & 2,380211 & 2,6388251 & 5,66540556 & 3,866524843 & 347,836 & 0,386969084 & 41,7164 \\
\hline Jumlah & & 16,2416 & 12,74269 & 33,333622 & 22,5198079 & 25,01010018 & & & \\
\hline
\end{tabular}

Tabel 12. Nilai Variabel untuk Perhitungan Intensitas Hujan PUH 50 Tahun Metoda Ishiguro

\begin{tabular}{ccccccccc}
\hline $\mathrm{t}$ & $\mathrm{I}$ & $\mathrm{t}^{0,5}$ & $\mathrm{I}^{\mathrm{t} \mathrm{t}^{0,5}}$ & $\mathrm{I}^{2}$ & $\mathrm{I}^{2} \mathrm{x} \mathrm{t}^{0,5}$ & $\mathrm{a}$ & $\mathrm{b}$ & $\mathrm{I}$ \\
\hline $\mathrm{a}$ & $\mathrm{b}$ & $\mathrm{c}=\mathrm{a}^{\mathrm{0,5}}$ & $\mathrm{d}=\mathrm{bx} \mathrm{a}$ & $\mathrm{e}=\mathrm{b}^{2}$ & $\mathrm{f}=\mathrm{b}^{2} \times \mathrm{t}^{0,5}$ & $\mathrm{~g}$ & $\mathrm{~h}$ & $\mathrm{i}=\mathrm{g}(\mathrm{Va}+\mathrm{h}$ \\
\hline 5 & 201,10 & 2,23607 & 449,6809 & 40442,59 & 90432,3742 & 865,7667131 & 1,53503 & 229,5795909 \\
10 & 176,89 & 3,16228 & 559,3651 & 31288,93 & 98944,2953 & 865,7667131 & 1,53503 & 184,3113356 \\
20 & 151,62 & 4,47214 & 678,0529 & 22987,79 & 102804,513 & 865,7667131 & 1,53503 & 144,1223668 \\
40 & 120,03 & 6,32456 & 759,1384 & 14407,28 & 91119,6188 & 865,7667131 & 1,53503 & 110,1542738 \\
60 & 105,29 & 7,74597 & 815,5709 & 11085,93 & 85871,2572 & 865,7667131 & 1,53503 & 93,28382625 \\
80 & 91,60 & 8,94427 & 819,3139 & 8390,94 & 75050,8637 & 865,7667131 & 1,53503 & 82,61684518 \\
120 & 66,33 & 10,9545 & 726,6366 & 4400,01 & 48199,6537 & 865,7667131 & 1,53503 & 69,31968021 \\
240 & 42,12 & 15,4919 & 652,4567 & 1773,75 & 27478,8023 & 865,7667131 & 1,53503 & 50,84681197 \\
\hline Jumlah & 954,98 & 59,33 & 5460,22 & 134777,21 & 619901,38 & & & \\
\hline
\end{tabular}

Dari nilai konstanta masing-masing metoda, maka diperoleh persamaan intensitas hujan untuk ketiga metoda terangkum dalam Tabel 13 berikut.

Tabel 13. Rumus Intensitas Hujan untuk PUH 10 Tahun

\begin{tabular}{ccc}
\hline \multicolumn{3}{c}{ Metoda Perhitungan Intensitas Hujan Rencana } \\
\hline Talbot & Sherman & Ishiguro \\
\hline $\mathrm{I}=\frac{12245,32062}{58,26453308+t} \mathrm{I}=\frac{347,836}{t^{0,4}}$ & $\mathrm{I}=\frac{865,767}{\sqrt{t}+1,535}$ \\
\hline
\end{tabular}

Setelah memperoleh persamaan intensitas curah hujan PUH 50 tahun, maka untuk mencari intensitas tiap waktu dapat dihitung dengan mensubstitusikan nilai waktu (t) ke tiap persamaan. Kemudian, dicari selisih intensitas hujannya. Perhitungan untuk mencari selisih hujan dengan PUH 50 tahun disajikan dalam Tabel 14. 
Tabel 14. Selisih Intensitas Hujan PUH 10 Tahun Metoda Talbot, Sherman dan Ishiguro

\begin{tabular}{|c|c|c|c|c|c|c|c|}
\hline $\begin{array}{c}\mathrm{t} \\
\text { (menit) } \\
\end{array}$ & I Data & I Talbot & $\begin{array}{l}\text { Selisi I Data } \\
\text { dan I Talbot }\end{array}$ & I sherman & $\begin{array}{c}\text { Selisih I Data } \\
\text { dan I Sherman }\end{array}$ & I Ishiguro & $\begin{array}{l}\text { Selisih I data } \\
\text { dan I Ishiguro }\end{array}$ \\
\hline $\mathrm{a}$ & $\mathrm{b}$ & c & $d=b-c$ & $\mathrm{e}$ & $f=b-e$ & $\mathrm{~g}$ & $h=b-g$ \\
\hline 5 & 201,10 & 193,55743 & 7,55 & 186,59 & 14,51 & 229,5796 & 28,48 \\
\hline 10 & 176,89 & 179,38042 & 2,49 & 142,69 & 34,19 & 184,3113 & 7,42 \\
\hline 20 & 151,62 & 156,46066 & 4,84 & 109,12 & 42,49 & 144,1224 & 7,49 \\
\hline 40 & 120,03 & 124,61587 & 4,59 & 83,45 & 36,58 & 110,1543 & 9,88 \\
\hline 60 & 105,29 & 103,54178 & 1,75 & 71,33 & 33,96 & 93,28383 & 12,01 \\
\hline 80 & 91,60 & 88,564438 & 3,04 & 63,82 & 27,78 & 82,61685 & 8,99 \\
\hline 120 & 66,33 & 68,69185 & 2,36 & 54,55 & 11,78 & 69,31968 & 2,99 \\
\hline 240 & 42,12 & 41,055235 & 1,06 & 41,72 & 0,40 & 50,84681 & 8,73 \\
\hline \multicolumn{2}{|c|}{ Jumlah } & & 27,67 & & 201,70 & & 85,98 \\
\hline \multicolumn{2}{|c|}{ Rata-rata } & & 3,46 & & 25,21 & & 10,75 \\
\hline
\end{tabular}

Tabel 14 menunjukkan bahwa dari ketiga metoda perhitungan intensitas hujan rencana yang digunakan, didapatkan nilai selisih (delta) intensitas hujan terkecil dengan intensitas hujan data adalah metoda Talbot sehingga rumus Talbot ini dianggap yang paling dapat mempresentasikan lengkung intensitas hujan. Metoda ini yang terkait dengan metoda Van Breen. Rumus yang digunakan untuk menghitung intensitas hujan PUH 50 tahun adalah dengan persamaan berikut $\mathrm{I}=\frac{12245,32062}{58,26453308+t}$

\section{Analisis Debit Air Rencana}

Setelah diketahui rumus untuk digunakan dalam perhitungan intensitas hujan PUH 50 tahun, maka selanjutnya ialah melakukan analisa debit air rencana. Analisa ini difungsikan untuk menghitung besarnya debit yang terjadi yang akan digunakan untuk perencanaan cross drain. Analisa ini menggunakan rumus rasional sebagai berikut:

$$
\mathrm{Q}=\mathrm{C} \times \mathrm{I} \times \mathrm{A}
$$

Dimana :

$\mathrm{Q}=$ Debit banjir rencana

$\mathrm{I}=$ Intensitas hujan

$\mathrm{A}=$ Luas daerah tangkapan hujan

(sumber : Suripin, 2004)

Adapun data yang dibutuhkan ialah :

1. Panjang Saluran

Panjang saluran didapatkan dari data pemetaan di google earth, untuk Sta 10+700 didapat $1297 \mathrm{~m}$ dan pada sta $11+700$ didapat $1247 \mathrm{~m}$.

2. Kecepatan Aliran

Untuk besarnya kecepatan aliran didapat dari tabel 15, menyesuaikan kondisi eksisting berupa batuan besar maka menggunakan kecepatan 1,5 m/det. 
Tabel 15. Selisih Intensitas Hujan PUH 10 Tahun Metoda Talbot, Sherman dan Ishiguro

\begin{tabular}{clc}
\hline No. & Jenis Bahan & Kecepatan aliran air yang diijinkan (m/detik) \\
\hline 1 & Pasir halus & 0.45 \\
2 & Lempung kepasiran & 0.50 \\
3 & Lanau aluvial & 0.60 \\
4 & Kerikil halus & 0.75 \\
5 & Lempung kokoh & 0.75 \\
6 & Lempung padat & 1.10 \\
7 & Kerikil kasar & 1.20 \\
8 & Batu-batu besar & $\mathbf{1 . 5 0}$ \\
9 & Pasangan batu & 1.50 \\
10 & Beton & 1.50 \\
11 & Beton bertulang & 1.50 \\
\hline : Pd.T-02-2006B)
\end{tabular}

3. Nilai Koefisien Pengaliran

Berdasarkan kondisi daerah aliran merupakan daerah pegunungan berlereng terjal maka menggunakan nilai 0,75 , sesuai yang tertera pada tabel 16.

Tabel 16. Harga Koefisien Pengaliran

\begin{tabular}{|c|c|c|c|c|}
\hline \multirow[t]{2}{*}{ No } & \multirow[t]{2}{*}{ Kondisi permukaan tanah } & \multicolumn{3}{|c|}{ Koefisien pengaliran ( C ) } \\
\hline & & & & \\
\hline 1 & Jalan beton dan jalan aspal & 0,7 & - & 0,95 \\
\hline 2 & Jalan kerikil dan jalan tanah & 0,4 & - & 0,7 \\
\hline \multirow[t]{6}{*}{3} & Bahun jalan & & & \\
\hline & - Tanah berbutir halus & 0,4 & - & 0,65 \\
\hline & - Tanah berbutir kasar & 0,1 & - & 0,2 \\
\hline & - Batuan masif keras & 0,7 & - & 0,85 \\
\hline & - Batuan masif lunak & 0,6 & - & 0,75 \\
\hline & TATA GUNA LAHAN & & & \\
\hline 1 & Daerah perkotaan & 0,7 & - & 0,95 \\
\hline 2 & Daerah pinggir kota & 0,6 & - & 0,7 \\
\hline 3 & Daerah Industri & 0,6 & - & 0,9 \\
\hline 4 & Daerah permukiman & 0,4 & - & 0,6 \\
\hline 5 & Permukiman padat & 0,4 & - & 0,6 \\
\hline 6 & Permukiman tidak padat & 0,2 & - & 0,4 \\
\hline 7 & Persawahan & 0,45 & - & 0,6 \\
\hline 8 & Perbukitan & 0,7 & - & 0,8 \\
\hline 9 & Pegunungan & 0,75 & - & 0,9 \\
\hline
\end{tabular}

4. Nilai kemiringan saluran (So)

Untuk besarnya kemiringan lereng didapat dari Google earth, untuk Sta 10+700 didapat 0,2 dan pada sta $11+700$ didapat 0,18 . 
5. Panjang Limpasan (Lo)

Panjang saluran didapatkan dari data pemetaan di Google Earth, untuk Sta 10+700 didapat $346 \mathrm{~m}$ dan pada sta $11+700$ didapat $697 \mathrm{~m}$

6. Waktu konsentrasi

Waktu konsentrasi merupakan jumlah dari waktu aliran di permukaan (to) dan waktu aliran di saluran (ts)

Setelah diketahui semuanya maka dapat dilakukan perhitungan nilai debit air rencana seperti yang tersaji pada tabel berikut.

Tabel 16. Perhitungan Nilai Debit Air Rencana ( Q )

\begin{tabular}{ccccccccccc}
\hline Lokasi & $\mathrm{L}$ & $\mathrm{v}$ & $\mathrm{A}$ & $\mathrm{C}$ & $\mathrm{S}$ & Lo & to & ts & I & $\mathrm{Q}$ \\
\hline & $\mathrm{m}$ & $\mathrm{m} / \mathrm{det}$ & $\mathrm{km}^{2}$ & - & $\mathrm{m} / \mathrm{m}$ & $\mathrm{m}$ & jam & jam & $\mathrm{mm} / \mathrm{jam}$ & $\mathrm{m}^{3} / \mathrm{det}$ \\
\hline Sta 10+750 & 1297 & 1,5 & 0,45 & 0,75 & 0,20 & 346 & 0,014185 & 0,240185 & 161,1039 & 15,10349 \\
Sta 11+700 & 1247 & 1,5 & 0,76 & 0,75 & 0,18 & 697 & 0,018945 & 0,230926 & 161,369 & 25,55009 \\
\hline
\end{tabular}

\section{Perencanaan Dimensi Cross Drain}

Setelah didapat nilai debit banjir rencana maka selanjutnya dilakukang penghitungan dimensi cross drain sesuai dengan debit air rencana. Untuk tipe cross drain uang melintas dibawah jalan raya dipilih menggunakan tipe cross drain box culvert. Menurut Chow (1997) untuk menghitung tinggi muka air dan lebar saluran menggunakan persamaan berikut

$$
\begin{aligned}
& \mathrm{Q}=\mathrm{V} \times \mathrm{A} \\
& \text { Dimana } \\
& \mathrm{Q}=\text { Debit Saluran } \\
& \mathrm{V}=\text { Kecepatan air dalam saluran } \\
& \mathrm{A}=\text { Luas penampang basah } \\
& \text { (sumber: Chow, 1997) }
\end{aligned}
$$

Untuk nilai $\mathrm{V}$ menggunakan nilai yang sama dengan nilai $\mathrm{V}$ pada analisis debit air rencana, sedangkan nilai A dilakukan percobaan trial and error sehingga mendapatkan dimensi yang sesuai dengan debit air rencana . Nilai A berdasarkan dimensi box culvert yang ditetapkan bina marga. Untuk tinggi jagaan (f) digunakan 0,2 m. Perhitungannya disajikan pada tabel 17 dan tabel 18.

Tabel 16. Perhitungan Dimensi Box Culvert pada Sta $10+750$

\begin{tabular}{cccccccc}
\hline $\mathrm{V}$ & $\mathrm{b}$ & $\mathrm{h}(\mathrm{m})$ & $\mathrm{f}(\mathrm{m})$ & $\mathrm{A}$ & $\mathrm{Q}_{\text {box culvert }}$ & $\mathrm{Q}_{\text {rencana }}$ & \multirow{2}{*}{ CHECK } \\
\cline { 1 - 6 }$(\mathrm{m} / \mathrm{s})$ & $(\mathrm{m})$ & $(\mathrm{m})$ & $(\mathrm{m})$ & $\left(\mathrm{m}^{2}\right)$ & $\left(\mathrm{m}^{3} / \mathrm{s}\right)$ & $\left(\mathrm{m}^{3} / \mathrm{s}\right)$ & \\
\hline 1,5 & 3 & 2,8 & 0,2 & 9 & 13,5 & 15,10349 & FALSE \\
1,5 & 4 & 1,8 & 0,2 & 8 & 12 & 15,10349 & FALSE \\
1,5 & 4 & 2,3 & 0,2 & 10 & 15 & 15,10349 & FALSE \\
1,5 & 4 & 2,8 & 0,2 & 12 & 18 & 15,10349 & CORRECT \\
\hline
\end{tabular}


Tabel 17. Perhitungan Dimensi Box Culvert pada Sta 11+70

\begin{tabular}{cccccccc}
\hline $\mathrm{V}$ & $\mathrm{b}$ & $\mathrm{h}(\mathrm{m})$ & $\mathrm{f}(\mathrm{m})$ & $\mathrm{A}$ & $\mathrm{Q}_{\text {box culvert }}$ & $\mathrm{Q}_{\text {rencana }}$ & \multirow{2}{*}{ CHECK } \\
\cline { 1 - 6 }$(\mathrm{m} / \mathrm{s})$ & $(\mathrm{m})$ & $(\mathrm{m})$ & $(\mathrm{m})$ & $\left(\mathrm{m}^{2}\right)$ & $\left(\mathrm{m}^{3} / \mathrm{s}\right)$ & $\left(\mathrm{m}^{3} / \mathrm{s}\right)$ & \\
\hline 1,5 & 5 & 1,8 & 0,2 & 10 & 15 & 25,55009 & FALSE \\
1,5 & 5 & 2,3 & 0,2 & 12,5 & 18,75 & 25,55009 & FALSE \\
1,5 & 5 & 2,8 & 0,2 & 15 & 22,5 & 25,55009 & FALSE \\
1,5 & 6 & 2,8 & 0,2 & 18 & 27 & 25,55009 & CORRECT \\
\hline
\end{tabular}

Setelah dilakukan perhitungan maka didapat dimensi box culvert yang sesuai. Pada sta 10+750 didapat dimensi box culvert $4 \mathrm{~m} \mathrm{x} 3 \mathrm{~m}$, sedangkan pada sta 11+700 didapat dimensi box culvert sebesar $6 \mathrm{~m} \times 3 \mathrm{~m}$.

\section{Penyesuaian Cross Drain dengan kondisi eksisting}

Pada sta $10+750$, kondisi eksisting memiliki kedalaman 16 meter sedangkan dimensi ideal box culvert untuk masa layan 50 tahun adalah $4 \mathrm{~m}$ x $3 \mathrm{~m}$. Dengan tinggi box culvert 3 meter, maka masih menyisakan kedalaman 13 meter lagi. Sisa kedalaman 13 meter bisa diminimalisir dengan cutting jalan pendekat menuju box culvert atau tanpa cutting tetapi dengan timbunan yang diperkuat. Tetapi dengan diketahui bahwa jarak lokasi cross drain sangat berdekatan dengan bibir pantai berjarak 15 meter serta mengingat bahwa masa layan cross drain tersebut untuk 50 tahun ke depan maka sebaiknya alternatif untuk sta $10+750$ adalah menggunakan jembatan model busur.

Pada sta 11+700, dimensi box culvert yang sesuai adalah $6 \mathrm{~m}$ x $3 \mathrm{~m}$. Dengan kondisi eksisting yang memiliki kedalaman 8 meter, sehingga menyisakan kedalaman 5 meter lagi. Dengan jarak antara lokasi cross drain dengan bibir pantai masih jauh berjarak 200 meter, maka penggunaan box culvert pada lokasi ini masih memungkinkan. Dengan alternatif melakukan cutting pada jalan pendekat menuju box culvert atau dengan timbunan yang diperkuat.

\section{KESIMPULAN}

Adapun kesimpulan dari evaluasi alternatif cross drain di ruas jalan nasional Selat Lampa - Teluk Depih - Sp. Sekunyam adalah sebagai berikut:

- Evaluasi menunjukkan debit limpasan pada kala ulang 50 tahun adalah $15,10 \mathrm{~m}^{3} /$ detik pada sta $10+750$, dan $25,55 \mathrm{~m}^{3} /$ detik pada sta $11+700$.

- Perencanaan dimensi box culvert yang sesuai untuk masa layan 50 tahun adalah $4 \mathrm{~m}$ x 3 $\mathrm{m}$ pada sta $10+750$, sedangkan untuk sta $11+700$ adalah box culvert dengan dimensi $6 \mathrm{~m}$ $\mathrm{x} 3 \mathrm{~m}$.

- Setelah dilakukan penyesuain dengan kondisi eksisting, maka pada sta 10+750 lebih sesuai jika menggunakan jembatan busur, sedangkan pada sta $11+700$ tetap menggunakan box culvert dengan penyesuaian cutting jalan pendekat atau dengan timbunan yang diperkuat.

\section{SARAN}

Pengamatan dan penelitian awal yang spesifik terhadap kondisi sekitar saat akan dilakukan pembangunan jalan sangat diperlukan, tidak hanya berpusat pada trase jalan rencana dengan radius yang pendek. Perlu diperluas lagi dalam pemetaan kondisi sekitar trase jalan tersebut sehingga bisa mengetahui detail kondisi kontur dan tata guna lahan sekitar. Maka kedepannya dapat mengantisipasi tidak terjadi hal hal seperti ini lagi. 
(e)ISSN 2615-1847 $\quad$ (p)ISSN 2615-1839

Jurnal Manajemen Aset Infrastruktur \& Fasilitas - Vol. 6, Edisi Khusus, Januari 2022

\section{DAFTAR PUSTAKA}

Adiwijaya. (2016). Modul Perencanaan Drainase Permukaan Jalan. Penerbit Pusat Litbang Jalan dan Jembatan. Bandung.

Asnaning A. R. (2020). "Evaluasi Dimensi Box Culvert pada Saluran Drainase Jalan Arteri Soekarno Hatta (Studi Kasus: Ruas Untung Surapati Hajimena)”. Jurnal Ilmiah Teknik Pertanian. Volume 12 no 1. April 2020.

Bambang Triatmodjo, (2010), Hidrologi Terapan, Beta Offset, Yogyakarta

Chow, VenTe \& Nensi Rosalina, (1997). Hidrolika Saluran Terbuka. Cetakan ke-4. Erlangga, Jakarta.

Dinata I. A. (2020). Laporan Akhir Kajian Geologi Teknik di Jalan Nasional Selat LampaSekunyam KM 8+375 - 9+600. Provinsi Kepulauan Riau.

Direktorat Jenderal Bina Marga. (2005). Standar Gorong-gorong Persegi Beton Bertulang (Box Culvert) Tipe Single. Departemen Pekerjaan Umum. Jakarta.

Direktorat Jenderal Bina Marga. (2005). Standar Gorong-gorong Persegi Beton Bertulang (Box Culvert) Tipe Double. Departemen Pekerjaan Umum. Jakarta.

Direktorat Jenderal Bina Marga. (2006). Perencanaan Sistem Drainase Jalan Pd-T02-2006$B$. Departemen Pekerjaan Umum. Jakarta.

Direktorat Jenderal Bina Marga. (2018). Spesifikasi Umum 2018 Untuk Pekerjaan Konstruksi Jalan dan Jembatan (Revisi 2). Kementerian Pekerjaan Umum dan Perumahan Rakyat. Jakarta.

Lestari U. S. (2016). "Kajian Metode Empiris untuk Menghitung Debit Banjir Sungai Negara di Ruas Kecamatan Sungai Pandan (Alabio)". Jurnal POROS TEKNIK Volume 8 No. 2. Desember 2016.

PPK 1.4 Satuan Kerja Pelaksanaan Jalan Nasional Wilayah I Provinsi Kepulauan Riau. (2020). Gambar Rencana Paket Pembangunan Jalan Selat Lampa Teluk Depih - Sp. Sekunyam (Pengalihan Trase) (UMYC). Provinsi Kepulauan Riau

Pranoto, Y. \& Padudung, Y.N. (2021). "Analisis Kapasitas Struktur Atas Jembatan Mahakam IV (Tipe Arch Bridge) Kalimantan Timur”. Jurnal Aplikasi Teknik Sipil Volume 19, No. 1. Februari 2021.

Satuan Kerja Non Vertikal P2JN Provinsi Kepulauan Riau. (2017). Perencanaan Teknis/ DED di Pulau Natuna Provinsi Kepulauan Riau. Provinsi Kepulauan Riau Satuan Kerja Pelaksanaan Jalan Nasional Wilayah I Kepulauan Riau.

Suprayitno, H. \& Soemitro, R.A.A. (2018). "Preliminary Reflexion on Basic Principle of Infrastructure Asset Management”. Jurnal Manajemen Aset Infrastruktur \& Fasilitas. Volome 2 No. 1. Maret 2018. 


\section{(e)ISSN 2615-1847 (p)ISSN 2615-1839}

Jurnal Manajemen Aset Infrastruktur \& Fasilitas - Vol. 6, Edisi Khusus, Januari 2022 